Article

\title{
Is Peru Prepared for Large-Scale Sustainable Rural Electrification?
}

\author{
Sarah Feron ${ }^{1,2, *}$ and Raúl R. Cordero ${ }^{2}$ \\ 1 Institute of Sustainability Governance, Leuphana University, 21335 Lüneburg, Germany; \\ 2 Department of Physics, Universidad Santiago de Chile, Santiago 9170124, Chile; raul.cordero@usach.cl \\ * Correspondence: sarah.feron@usach.cl; Tel.: +56-9-7742-6823
}

Received: 24 April 2018; Accepted: 18 May 2018; Published: 22 May 2018

check for updates

\begin{abstract}
Peru has historically been among the Latin-American countries with a low rural electrification rate. Aiming to improve this situation, the country conducted several electrification efforts in the last few decades that included off-grid photovoltaic (PV) solutions for remote areas (where the grid expansion was unviable). More recently, the government has also sponsored a 'massive program' that aims to deploy a minimum of 150,000 off-grid PV solutions in the upcoming years. In this paper, we assess the sustainability of rural electrification programs in Peru, paying special attention to the ongoing "massive program". Our assessment considers four dimensions of sustainability (institutional, economic, environmental, and socio-cultural) and is based on an exhaustive qualitative document analysis complemented by semi-structured expert interviews. We found that the lack of strong formal institutions with a flexible and decentralized structure seriously compromises the sustainability of rural electrification efforts in Peru. Staff rotation and overlapping competences have caused disturbing changes and inhibited following a strategic line, while widespread outsourcing combined with weak controls have often affected the reliability of the deployed systems. Although cross subsidies have made off-grid PV systems affordable for users, systems often fell short of energy demand. Notably, we found that Peruvian officials appear to be unaware of the importance of local participation, and there is a significant mistrust between the government and the rural population (especially in areas where mining is extensive). As a consequence, most of the projects are still designed without the participation and engagement of the communities, which has frequently led to project failures, payment defaults, and inhibited seizing opportunities regarding productive uses of off-grid PV systems. We expect that our findings may help Peruvian institutions to address the most severe drawbacks affecting their rural electrification efforts based on off-grid PV systems.
\end{abstract}

Keywords: rural electrification; off-grid PV; sustainability; sustainable energy; developing countries; renewable energy; social justice; sustainable institutions

\section{Introduction}

Although Peru has managed to considerably increase its rural electrification rate from 8\% in 1993 to $29.5 \%$ in 2007 and $78 \%$ in 2015 [1], it is still among the countries in Latin America with a low rural electrification rate. Though this increase was primarily due to grid expansions, the government has recently prioritized the deployment of off-grid photovoltaic (PV) systems, especially in the remote areas where the grid expansion is unviable. Communities of these areas are characterized by low energy demand, low income, high dispersion, and difficult accessibility [2].

In this paper, we critically analyse the current status and challenges of rural electrification programs (based on off-grid PV systems) in Peru. We aim to better understand drivers of success and highlight flaws that have compromised the sustainability of these efforts. Paying special attention to 
the ongoing deployment of 150,000 off-grid PV systems, we addressed the following research question: Are the Peruvian rural electrification programs based on off-grid PV systems sustainable?

In order to answer our research question, we conducted an exhaustive qualitative document analysis complemented by semi-structured expert interviews. This approach has been broadly used for the assessment of sustainability (see, for example, [3-7]). The interviewees included experts from different ministries, project managers from leading Non-Governmental Organizations (NGOs), public and private companies' representatives, supervisors, and researchers. Although below we describe several relevant PV-based electrification efforts in Peru, our research was aimed at gathering an overall picture of the rural electrification efforts in the country, rather than measuring the success or failure of a specific project.

The gathered information allowed us to assess the sustainability of rural electrification efforts in Peru. Our assessment was based on a set of indicators (adopted from [7]) corresponding to the four dimensions of sustainability considered in this paper: institutional, economical, environmental, and socio-cultural. Additional methodological details are provided below.

Institutional sustainability has been acknowledged as an important factor for the sustainability of rural electrification initiatives (see, e.g., [8,9]). For institutions to be sustainable, they need to be stable and durable [10-12]. In that context, Gollwitzer [13] highlights the importance of the organizational set-up, which includes adopting and enforcing norms and regulations. Authors further agree that, for an effective sustainable energy development, the openness to participation of all stakeholders is imperative [14-16]. The participation is important for decentralization, which makes sense not only because of numerous technical advantages of decentralized renewable energy (RE) solutions [17,18], but also because it favors the adaptability of the institutions. Indeed, sustainable institutions must have the ability to adapt to the needs of the country over time $[8,11,14,19]$.

Economic sustainability of electrification solutions requires ensuring the affordability of the systems $[19,20]$, which implies adopting cost-effective solutions and procuring funding for both the initial investment and the operation and maintenance (O\&M) of the systems [11,21-23]. Access to electricity is also expected to contribute to an increase in household income of users [24,25]. However, contributing to the income of users also requires ensuring the reliability of the energy systems [26]. Dunmade [23] and Chaurey and Kandpal [27] therefore stress the importance of local availability of spare parts for adequate maintenance and a reduction of its downtime.

The lack of awareness and citizen participation in environmental decision-making may thwart the progress towards environmental sustainability [28]. Awareness should hence be assessed in evaluations of energy choices; for instance, it has been found that RE could contribute to greater environmental awareness of citizens in remote areas, and even motivate them to participate in environmental initiatives of other fields [29]. However, not only the awareness of environmental concerns is appraised in environmental sustainability, but also the prevention of negative environmental impacts (e.g., $[11,14,20])$; these impacts may be of global or of local nature $[8,20]$. Besides the mitigation of greenhouse gases, environmental impacts also concern the conservation of a stable resource base, the safeguard of biodiversity, the prevention of deforestation, avoidance of noise, and waste management $[14,23,30]$. For off-grid PV systems and particularly their batteries, this implies that the waste disposal requires a proper treatment, as the impact evaluation must consider the whole lifecycle of a technology [31,32].

Socio-cultural sustainability is closely related to the notion of social justice, as access to modern energy can contribute to better living conditions due to a healthier environment, access to information (e.g., radio or TV), higher security (through public lighting), and better education $[8,11,12,20]$. The equity in the amount of energy consumption per capita as well as the disparity of energy use between different groups of people (e.g., according to gender, ethnical background, etc.) determines the accessibility $[9,10,20,33]$. Moreover, an energy solution can be considered to be sustainable if it is accepted by the society, which will depend on multiple factors, including the consideration of culture 
and traditions in the energy planning [23,34]; the participation of the local community [9,14]; and the exchange of information aimed at learning experiences and knowledge-sharing [35].

Based on this theoretical framework, we have built up a set of indicators (see Table 1; see also [7]) clustered into the four dimensions (institutional, economic, environmental, and socio-cultural) of sustainability considered in this paper. These indicators were used to qualitatively evaluate to what extent Peru's rural electrification efforts based on off-grid PV systems are sustainable.

Table 1. Indicators of sustainability used in this study (adapted from [7]).

\begin{tabular}{cccc}
\hline Institutional & Economic & Environmental & Social/Cultural \\
\hline Stability (Durability) & Cost effectiveness & $\begin{array}{c}\text { Environmental } \\
\text { awareness }\end{array}$ & $\begin{array}{c}\text { Accessibility } \\
\text { (disparity, equity) }\end{array}$ \\
\hline Regulation and Standards & Reliability & Environmental impact & Social Acceptance \\
\hline $\begin{array}{c}\text { Decentralization and } \\
\text { Openness to participation }\end{array}$ & $\begin{array}{c}\text { Funding (initial investment; } \\
\text { operation and maintenance) }\end{array}$ & Accuracy \\
\hline $\begin{array}{c}\text { Adaptability (ability to meet } \\
\text { future needs) }\end{array}$ & $\begin{array}{c}\text { Contribution to income of } \\
\text { users }\end{array}$ & Cultural Justice \\
\hline
\end{tabular}

\section{Materials and Methods}

In order to assess the sustainability of off-grid PV projects in Peruvian rural areas, we conducted a qualitative document analysis [36] complemented with semi-structured interviews [3].

The document analysis enabled us to gather important insights on electrification programs and cases, regulations, policies, and statistical data on rural electrification in Peru. It included public documentations such as the National Plan of Rural Electrification (PNER by its Spanish acronyms); electrification laws and regulations; energy pricing models; statistic databases; publications on experiences from Peruvian electrification projects (case studies); project auditing; and scientific papers on related topics. This qualitative document analysis helped us with identifying and selecting experts for the semi-structured interviews.

The interviews allowed us to understand and to unearth issues that could not be unveiled by the document analysis; expert interviews have indeed been broadly used for the assessment of sustainability (see, for example, [3-7]). A total of 18 interviews were conducted, of which 15 were face-to-face interviews, and three interviews were held by Skype ${ }^{\circledR}$ (Berlin, Germany) in cases where the interviewees were not able to be reached personally; interviews lasted between 30 and $83 \mathrm{~min}$. Most of the interviews were recorded and transcribed afterwards, except for two cases where interviewees rejected be recorded. In these cases, handwritten notes were taken during the interview and complemented with additional notes right after the interviews had finished. The interviewees were of higher hierarchical positions (directors, project managers, leading researchers, and division leaders; see Table 2), as we were interested in the overall institutional and organizational conditions.

According to the four dimensions of sustainability, coding schemes were defined for the gathered information using MAXQDA ${ }^{\circledR}$ [37] software (Redmond, WA, USA) (see [38]). 
Table 2. Interview partners.

\begin{tabular}{|c|c|c|}
\hline Area & Sub-Area & Division (If Applicable) \\
\hline \multirow{3}{*}{$\begin{array}{l}\text { Government Institutions Energy } \\
\text { Sector }\end{array}$} & $\begin{array}{l}\text { Ministry of Energy - General Direction of } \\
\text { Rural Electrification (MEM-DGER) }\end{array}$ & $\begin{array}{c}\text { Direction of Grant Funds (DFC) } \\
\text { Project Management Direction (DPR) }\end{array}$ \\
\hline & $\begin{array}{l}\text { Supervisory Organization for Investment in } \\
\text { Energy and Mining (OSINERGMIN) }\end{array}$ & $\begin{array}{l}\text { Tariffs, Regulation and Tenders } \\
\text { Generation Off-Grid System }\end{array}$ \\
\hline & Consultant & High ranking administrative officer and consultant \\
\hline $\begin{array}{l}\text { Government Institutions } \\
\text { Non-Energy Sector }\end{array}$ & $\begin{array}{l}\text { Ministry of Development and Social } \\
\text { Inclusion (MIDIS) }\end{array}$ & Technical Project Coordination \\
\hline Academics and Research Institutes & Universities & $\begin{array}{c}\text { Sociologist } \\
\text { Technological Transition and Renewable Energies (RE) } \\
\text { RE Research Centre }\end{array}$ \\
\hline $\begin{array}{l}\text { Non-governmental } \\
\text { organizations(NGOs) }\end{array}$ & $\begin{array}{c}\text { ACCIONA } \\
\text { Soluciones Prácticas }\end{array}$ & $\begin{array}{l}\text { ACCIONA Microenergia Perú (AMP) } \\
\text { Renewable Energy (RE) Department }\end{array}$ \\
\hline Foreign Institutions & International Cooperation Agency (ICA) & Renewable Energy (RE) Department \\
\hline \multirow[t]{2}{*}{ Energy Companies } & Public Companies & $\begin{array}{c}\text { Electrical Infrastructure Administration Enterprise } \\
\text { (ADINELSA) } \\
\text { Electronoroeste (ENOSA) } \\
\text { Electro Oriente S.A. (ELOR) }\end{array}$ \\
\hline & Private Companies & $\begin{array}{c}\text { Servicios Especializados y Logística En General } \\
\text { (SELEGSA) } \\
\text { Green Energy } \\
\text { Ergon S.A. }\end{array}$ \\
\hline
\end{tabular}

Source: Own elaboration.

\section{Peru: Country Profile}

\subsection{General Background}

Peru's total population counted about 31 million in 2015 [39], of which the rural population represented 21\% in 2014, though its share is declining (e.g., in 1990, it still accounted for 31\%) [40]. Moreover, although total poverty has dropped from $58.7 \%$ in 2004 to $23.9 \%$ in 2013, rural poverty (48\%) remained significantly higher than urban poverty (16\%) [41].

Peru reformed its Constitution (law $\mathrm{N}^{\circ} 27680$ ) in 2002 to foster decentralization. The administrative division in Peru now comprises 24 departments that are governed by 26 regional governments; these departments consist of 196 provinces and 1854 districts [39,42]. In addition to restructuring its administrative division in 2002, the decentralization also entailed budget allocation to regional and local governments. However, budget allocation has neither come along with capacity building nor with the establishment of control and evaluation mechanism [43]. Furthermore, national and regional goals lacked any form of coordination (e.g., [43,44]).

This has led to poor results in decentralization, such that the country is recently showing trends of recentralization: e.g., whereas the annual budget of the central government accounted for $67 \%$ of the total budget in 2013 (16\% regional, 17\% local government), it increased to $75 \%$ in 2016 at the expense of the regional/local government budget (14\% regional, $11 \%$ local) [45].

\subsection{The Peruvian Energy Sector}

The Ministry of Energy and Mining (MEM) was founded in 1968 (Decree No. 17271; substituted by Decree 25962 in 1992). In 1972, the government passed the Normative Electricity Law (Decree Law No. 19521), which induced the nationalization of the electricity companies. It was exerted by the company ELECTROPERU, which was created the same year for that purpose. Ten years later (1982), the General Electricity Law was enacted, stipulating that energy distribution was passed on from ELECTROPERU to regional companies, while ELECTROPERU was converted to a public-private company [46].

In 1992, the enactment of the Electric Concession Law (No. 25844) privatized the electricity market (including parts of ELECTROPERU). The role of the state focused on the regulation of the sector. Privatization was not fully accomplished, as only 14 companies were privatized between 
1994 and 1997 [47]. As revealed by Torero and Pasco Font [47], privatization led to an increase in the electrification tariff of 6 cents per kilowatt hour (kWh) in 1996 to 10 cents/kWh in 1998, but the electrification rate did not progress as expected in urban areas [48]. Electrification rate in rural areas by contrast did increase due to higher investments in rural electrification, which remained in public hands and was therefore conducted by the MEM with public funds [48].

In the context of privatization in the 1990s, and in order to regulate the electricity, hydrocarbon and mining industries, the Organization for Investment in Energy and Mining was founded in 1996 with the name of OSINER (since 2007, the name changed to OSINERGMIN). In addition to its role as a supervisor, OSINERGMIN also sets electricity tariffs based on the policies defined by the MEM [49].

There are currently 43 electricity generation, nine transmission, and 23 distribution companies operating in Peru, which can be both public or private [50]. The electricity distribution companies (EDCs) are usually operating in small areas around urban centres; they have the obligation of providing electricity to clients that claim for energy and that are located within $100 \mathrm{~m}$ of the EDC's existing network [51].

Policies for RE are regulated in Decree 1002 (enacted in 2008), which stipulates national interest for the participation of RE in the energy mix. According to this Decree, every five years, the MEM defines a target share of RE of the national electricity consumption. Aiming to reach this target (currently 5\%), the Supreme Decree $\mathrm{N}^{\circ}$ 050-2008-EM stipulates a hybrid model with a request for proposals for RE (conducted biannually) coupled with a guaranteed feed-in tariff for 20-30 years [52]. For each technology, the MEM defines how much energy needs to be generated (possibly by several bidders) [52].

\subsection{Rural Electrification}

As in 1993, the rural electrification rate was about $8 \%$ (see Figure 1) and the private sector was not interested in electrifying remote areas, the MEM established a new division called Executive Project Management (DEP; Decree No. 021-93) to promote rural energy projects with special funds. Moreover, one year later, a new public EDC ('Electrical Infrastructure Administration Enterprise' (ADINELSA)) was founded to deal and manage rural electrification projects from local institutions (e.g., from municipalities). ADINELSAs clients are located outside the operation areas of others' EDCs.

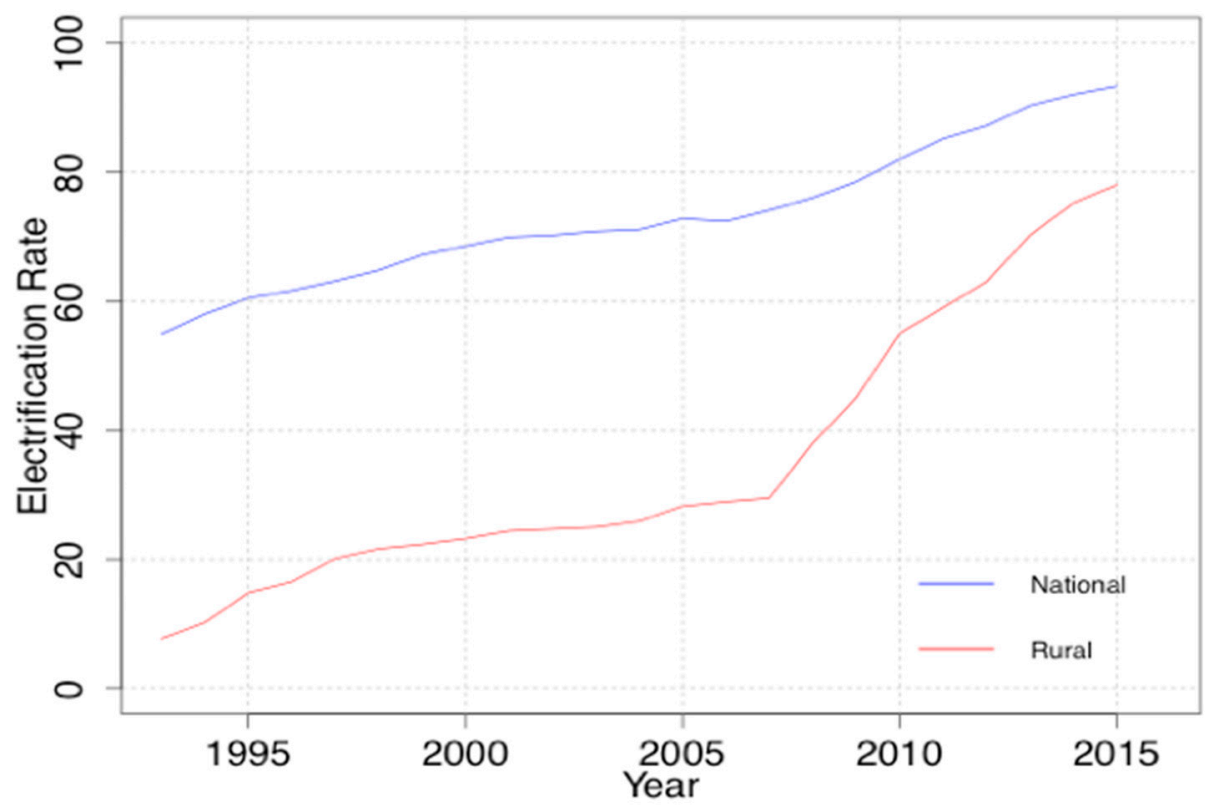

Figure 1. Electrification rate in Peru. Source: Own elaboration, based on data from [1]. 
In 2007, the DEP was merged with a project for rural electrification improvement, and renamed as General Direction of Rural Electrification (DGER). Later that year, the Direction of Grant Funds (DFC) and the Project Management Direction (DPR) were created to operate under the DGER [1]. While the DFC has been in charge of conducting electrification projects supported and funded by international organizations (e.g., Worldbank), the DPR acts by using national funds.

Rural electrification is regulated under the Law of Rural Electrification (Law 28749) enacted in 2006. It stipulates that the state is in charge of planning the rural electrification by means of the DGER. Owing to the alleged financial unattractiveness of this sector, the law allocates state subsidies to rural electrification [53]. The law further specifies that the DGER is responsible for elaborating the PNER, an annually published strategy paper on rural electrification with a time horizon of 10 years.

In the case of projects conducted by the central government aimed at rural electrification based on off-grid solutions (i.e., stand alone PV systems), although the regional or local governments request the electrification, the projects need approval from the MEM and from the Ministry of Economics and Finance (MEF). Projects are registered in a database, the National System of Public Investment (SNIP) to avoid project duplications [54]. If approval is given from both the MEM and the MEF, the EDC (or ADINELSA) of the region where the project is located will issue a request for tenders. The private company that wins the tender conducts the installation of the off-grid systems, but the EDC (or ADINELSA) will be in charge of O\&M [1,55].

Regional and local governments can also promote rural electrification projects with off-grid solutions, either in collaboration with the MEM, or on their own account (and financed from own resources); in the latter case, the approval from MEF/MEM is not necessary. When these energy systems become operative, the local/regional governments may lease or transfer the assets to the EDC of the region [56].

Among the rural electrification initiatives based on off-grid solutions, several projects are deploying stand-alone PV systems. Some of them are worth mentioning. Between 2006 and 2013 , the DFC conducted the Rural Electrification Improvement Project I (FONER I) in collaboration with the Worldbank that triggered rural electrification initiatives based on PV [57]. The DFC is currently running a follow-up project (FONER II), which will deploy a total of 11,000 off-grid PV systems [57].

Moreover, OSINERGMIN conducted a request for tenders (commissioned by the MEM) in 2014 to install between 150,000 and 500,000 stand-alone PV systems all around the country in the so-called 'massive program'. The contract was signed with the MEM/DPR in a public-private partnership; the installation started in August 2015 and completion was planned for mid 2016 [1]. The contract stipulates that the private company that won the tender, Ergon S.A., is in charge of the identification of potential users (by a survey), the installation, and the O\&M of the systems for 15 years; the administration (e.g., tariff collection) on the other hand will be carried out by the EDCs of the covered regions [58].

Typical PV systems for rural households from these programs have a capacity of 60 Watts peak (Wp) or below, and included a battery capacity ranging from 60 ampere hours (Ah) to 100 Ah; the PV modules may either be installed on the rooftop (e.g., in 52\% of the revised systems) of each dwelling, or on a pole-either way it is common to have one system per household [58]. The installations of all of the programs also contained a charge controller and three light bulbs [58].

Table 3 provides an overview of the rural electrification programs in Peru that have been analysed in this paper. The list includes public project as well as projects sponsored by NGOs. 
Table 3. Rural electrification programs based on off-grid Photovoltaic (PV) systems considered in this paper.

\begin{tabular}{|c|c|c|c|c|c|}
\hline & $\begin{array}{l}\text { Rural Electrification } \\
\text { Improvement } \\
\text { Project (FONER } \\
\text { I \& II) }\end{array}$ & $\begin{array}{l}\text { RE Programs from } \\
\text { the General } \\
\text { Direction of Rural } \\
\text { Electrification } \\
\text { (DGER) }\end{array}$ & Massive Program & Municipalities & $\begin{array}{c}\text { Non-Governmental } \\
\text { Organizations (NGOs) }\end{array}$ \\
\hline $\begin{array}{l}\text { Reports for ex-post } \\
\text { evaluations }\end{array}$ & {$[59,60]$} & {$[59,61,62]$} & NA & {$[59,63]$} & {$[59,64-71]$} \\
\hline Program sponsored by & $\begin{array}{l}\text { Direction of Grant } \\
\text { Funds (DFC) and, } \\
\text { Worldbank }\end{array}$ & $\begin{array}{l}\text { Project Management } \\
\text { Direction (DPR) }\end{array}$ & $\begin{array}{l}\text { Ministry of Energy } \\
\text { (DGER) }\end{array}$ & Municipalities & $\begin{array}{l}\text { ACCIONA Microenergía } \\
\text { Perú (AMP); German } \\
\text { Society for International } \\
\text { Cooperation (GIZ); } \\
\text { Soluciones Prácticas } \\
\text { Universities } \\
\text { Eurosolar }\end{array}$ \\
\hline Location & Nationwide & $\begin{array}{l}\text { Nationwide, among } \\
\text { others: Cajamarca, } \\
\text { Ucayali, Loreto, } \\
\text { Junin, Cusco, Pasco, } \\
\text { Ayachucho }\end{array}$ & $\begin{array}{l}\text { Nationwide } \\
\text { (divided into } \\
\text { northern, central, } \\
\text { and southern } \\
\text { Peru). }\end{array}$ & $\begin{array}{l}\text { Nationwide, among } \\
\text { others: Loreto, Puno, } \\
\text { Cajamarca, Ucayali, } \\
\text { Amazonas, Piura, Pasco, } \\
\text { Madre De Dios }\end{array}$ & $\begin{array}{l}\text { Cajamarca. Puno, San } \\
\text { Martin, Amazon, Cusco } \\
\text { Lambayeque, Piura, } \\
\text { Ayacucho, Huancavelica: } \\
\text { Ica, Junin, Tacna }\end{array}$ \\
\hline Energy use & $\begin{array}{l}\text { Residential rural } \\
\text { electrification; } \\
\text { electrification of } \\
\text { schools/health } \\
\text { centres/social } \\
\text { buildings }\end{array}$ & $\begin{array}{l}\text { Residential rural } \\
\text { electrification }\end{array}$ & $\begin{array}{l}\text { Residential rural } \\
\text { electrification; } \\
\text { electrification of } \\
\text { schools, health } \\
\text { centres and social } \\
\text { buildings }\end{array}$ & $\begin{array}{l}\text { Residential rural } \\
\text { electrification }\end{array}$ & $\begin{array}{c}\text { Residential rural } \\
\text { electrification (Solar Home } \\
\text { Systems (SHS) and Solar } \\
\text { Pico Systems (SPS); Schools } \\
\text { and Churches, Health } \\
\text { Centres, } \\
\text { Community Centres }\end{array}$ \\
\hline Capacity/Sizing * & $\begin{array}{c}\text { FONERI: } 60 \text { Watt } \\
\text { peak }(\mathrm{Wp}) \\
\text { FONERII: } 60 \mathrm{Wp}, 80 \\
\text { Wp were proposed } \\
\text { for future } \\
\text { installations } \\
\end{array}$ & $\begin{array}{c}\text { PER/96/028: } 50 \mathrm{Wp} \\
\text { PER/98/G31: 35-51 } \\
\text { Wp }\end{array}$ & $120 \mathrm{Wp}$ & $50 \mathrm{Wp}$ & $\begin{array}{c}\text { Renewable Energy Center } \\
\text { (CER-UNI): } 45-50 \mathrm{Wp} \\
\text { AMP: } 60-80 \mathrm{Wp} \\
\text { Eurosolar: } 1400 \mathrm{Wp} \text { (hybrid } \\
\text { solar-wind systems) }\end{array}$ \\
\hline Year of installations & $\begin{array}{l}\text { FONER I: 2006-2011 } \\
\text { FONER II: Since } 2012\end{array}$ & Since 1996 & Since 2015 & $\begin{array}{l}\text { Various, e.g.,: Regional } \\
\text { Government of Tacna: } \\
\text { 2007-2008 } \\
\text { Regional Government of } \\
\text { Cajamarca and } \\
\text { Loreto: } 2011\end{array}$ & $\begin{array}{l}\text { CER-UNI: 1986-1987, } \\
\text { 1995/1996, 1999 } \\
\text { AMP: Since } 2009 \\
\text { Eurosolar: } 2011 \\
\text { Soluciones Practicas: } \\
\text { 2006/2007 } \\
\end{array}$ \\
\hline $\begin{array}{c}\text { Number of } \\
\text { installations/households } \\
\text { electrified }\end{array}$ & $\begin{array}{l}\text { FONER I: } 9115 \\
\text { FONER II: } 20,000\end{array}$ & $\begin{array}{l}\text { PER/96/028: } 1523 \\
\text { PER/98/G31: } 4200\end{array}$ & $150,000-500,000$ & $\begin{array}{l}\text { Estimation of total users: } \\
6197\end{array}$ & $\begin{array}{c}\text { CER-UNI: } 100,451,781 \\
\text { (different projects) } \\
\text { AMP: } \sim 3900 \\
\text { Eurosolar: } 130 \text { communities } \\
\text { (902 panels) }\end{array}$ \\
\hline
\end{tabular}

* Plant sizes were defined up front independently of the individual needs; see "accuracy" in Section 4.4.

\section{Results}

\subsection{Institutional Sustainability}

\subsubsection{Stability (Durability)}

Although the PNER includes a long-term perspective on rural electrification aiming to assure planning security to the electrification policy, reality has diverged from this objective. Abrupt political changes in the energy sector have inhibited following a clear and strategic policy line. According to a representative of OSINERGMIN, these political changes have been an issue for RE policies as the RE quota has been fixed depending on who is in the government, thus leading to high uncertainty. Moreover, the staff rotation in the MEM caused by political changes has led to a loss of know-how.

Furthermore, mistrust towards formal institutions is widespread in Peru. The red tape in the public sector was an often-named problem, which has led to animosity towards the governments and the public institution in general. The lack of trust in the government may have also contributed to widespread outsourcing. In rural electrification, the installation of off-grid PV systems and their O\&M is outsourced; the regulatory agency (OSINERGMIN) has even outsourced the supervision of these outsourced activities. 


\subsubsection{Regulation and Standards}

Technical standards for off-grid PV systems in Peru are not up to date (e.g., technology for light bulbs has improved considerably in the meantime) [72]. Additionally, the quality of the mostly imported components of off-grid PV systems is not controlled, which has resulted e.g., in premature battery failures. Due to the lack of quality standards, rural electrification projects (particularly those implemented by local governments) are compromised by the use of very poor qualitative parts.

OSINERGMIN's supervision of the EDCs has indeed been weak regarding off-grid PV systems for rural electrification. In fact, up to now, only two punctual revisions were conducted by OSINERGMIN in 2011 and 2013, where a total of 1110 off-grid PV systems from different public and private projects were inspected. Out of these 1110 revised systems, 34\% were found inoperative [59]. Part of the problem is that, in Peru, regulations are not clear regarding what actions to take and who is held responsible if the systems are not operative.

Some interviewees have also described the lack of technical standards as a problem affecting the "massive program". A representative of OSINERGMIN admitted that many technical details were not included in the request for tenders of the "massive program". As a consequence, disagreements between the MEM and Ergon concerning the technical standards of the systems delayed their implementation in 2015.

\subsubsection{Decentralization and Openness to Participation}

Article 3 of the law of Rural Electrification specifies that the MEM shall develop projects for rural electrification in collaboration with regional and local governments. However, the MEM is centrally designing the projects, without the participation of those who are closest to the community (i.e., the EDCs). Moreover, the role of the rural communities is limited and they are not involved at all in the design and implementation of projects.

Decentralization (understood as redistribution of the funds to elected local governments) has allowed local or regional governments to implement electrification projects by themselves. However, as mentioned above, these projects have been rarely successful. Indeed, though the number may not be representative, the two supervisions conducted by OSINERGMIN $(2011 / 2013)$ found that only one out of 29 supervised PV systems implemented by municipalities was operative [59]. A representative of the Ministry of Development and Social Inclusion (MIDIS) explained these flaws by the fact that, although funds were remitted from the national to local and regional governments, they were not accompanied by development programs and technical assistance to the local governments.

Decentralization in Peru has also been plagued by a lack of coordination. Although projects implemented by local or regional governments should be registered in the SNIP to avoid duplications, this is often not occurring. Furthermore, the data the government holds on rural electrification are not up to date. In fact, electrification rate published by the MEM diverged considerably from other databases (such as census data) [56].

The lack of reliable data also became evident in the case of the "massive program". The MEM gave Ergon a tentative database of the communities that lack electricity access, but many of the communities from the MEM's database were already electrified. In fact, in the request for tenders of the "massive program", the number of installations under contract was not set partially due to the fact that the actual number of households without electricity is still unknown.

\subsubsection{Adaptability}

The sustainability of rural electrification programs demands for institutions that have the capacity to adapt to the situation of a country and its needs. This normally implies having strong formal institutions with a flexible and decentralized structure [73,74]. However, regarding rural electrification, the organization of the MEM/DGER hardly meets these criteria. 
Currently, two agencies (DFC and DPR) both under the MEM/DGER, conduct off-grid PV projects for rural electrification. The need of having two agencies both focused on rural electrification is not clear. Although project proposals for rural electrification from across the country are presented to the DGER and thereinafter assigned to either one of the agencies, there are no written criteria that determine to which one a project is assigned. Competences of both agencies appear to be overlapping, which has caused a rivalry between them.

Several interviewees argued that projects from the DFC were technically superior to those from the DPR. The difference may be due to the fact that the DFC has vast experience in off-grid PV system installations, whereas, until very recently, the DPR had no interest in PV. Still, the "massive program" is being coordinated by the DPR, leaving the DFC completely out.

The lack of a single agency with the responsibility of promoting and overseeing all rural electrification programs in the country seems to be a major drawback, which compromises the ability of Peruvian institutions to ensure the sustainability of off-grid PV projects (including the "massive program"). In addition, the current regulations may not be flexible enough for allowing EDCs to adapt to the particularities of the communities. For example, aiming to meet the needs of isolated communities in remote areas, several interviewees mentioned a variety of applications such as Solar Pico Systems (SPS) (i.e., small-scale solutions of $0.3 \mathrm{Wp}$ up to $10 \mathrm{Wp}$ such as solar lanterns; see [75] for details). SPS may be useful in remote regions that EDC technicians cannot reach regularly as well as for nomad communities (who change their dwelling several times per year). However, SPS solutions have not yet been considered in government projects and, recently, the MEM rejected a proposal of the German Corporation for International Cooperation (GIZ by its German acronym) to consider SPS for remote areas. This example shows that Peruvian institutions still have problems to adapt to the needs of different communities, which inhibit seizing opportunities.

\subsection{Economic Sustainability}

\subsubsection{Cost Effectiveness and Reliability}

In order to be sustainable, a solution for electrification must be cost-effective. In remote areas of Peru, conventional grid expansions have shown to be too difficult and expensive [59]. In these cases, off-grid PV systems are a cost-effective alternative and, therefore, several EDCs and NGOs have been deploying off-grid solutions in these areas for years.

Aimed at cost-effectiveness, basically all EDCs (and NGOs) have outsourced both installations and O\&M services to local firms. Moreover, some of the EDCs have recognized the advantage of economies of scale. According to a representative of ADINELSA, they attained lowering the monthly O\&M costs from about S/.60 to S/.50 (US\$20 to US\$17) per user by increasing the number of off-grid $\mathrm{PV}$ clients across the country. Indeed, the "massive program" was designed following the approach of economies of scale.

In the case of the "massive program", the tender bid winner (Ergon) expects the program's costs per user to be very low, even below the current subsidy paid to the public EDCs in the southern region: Ergon will receive US $\$ 8,370,054$ per year (for 15 years) for 50,000 users (i.e., about US\$167 per system per year) [76]. This is nearly half of the price offered by the second bidder in the same area (that had bidden US $\$ 16,703,235)[76]$. This difference has been highlighted by several interviewees that were quite sceptical about the reliability of the service offered by Ergon. Indeed, although the contract of the "massive program" stipulates that Ergon must execute all maintenance tasks, no contractual obligation existed to conduct revisions at a fixed period [77].

Reliability of PV systems has already been an issue in Peru for the implemented systems, especially regarding O\&M, as public EDCs are under considerable strain to make profits (and rural electrification is a losing deal for them). Moreover, several interviewees explained that most EDCs do not have spare parts for off-grid PV systems in their stock. 


\subsubsection{Funding}

Sustainability of off-grid PV systems requires ensuring funding for the initial investment and the O\&M. In Peru, government intervention is inevitable for ensuring funding because rural populations in remote areas are usually poor and can neither afford the systems nor their O\&M. Fortunately, budget allocation to rural electrification has increased substantially since 2007, which has contributed to the great increase of the rural electrification rate, as shown by the red line in Figure 2. As explained above, the initial investment of off-grid PV systems may stem from different sources (e.g., state budget, fines, etc.).

Nevertheless, even the poorest inhabitants of remote areas are expected to contribute to the O\&M costs. In Peru, OSINERGMIN fixes the electricity tariffs for urban and remote users, including for off-grid PV systems. For the latter, tariffs are set every four years, and they may vary according to three main factors: (1) who is the investor (private or public company); (2) the size of the PV modules; and (3) the location (coastal lowlands, Andean highlands, Amazon basin, or special Amazon regions) that determines the amount of energy disposed respectively.

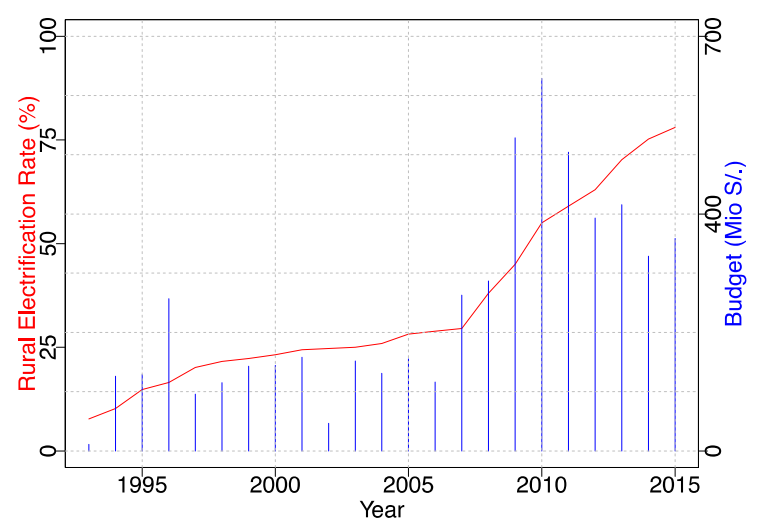

Figure 2. Rural electrification budget (in Million S/.) vs. rural electrification rate. Source: Own elaboration based on [1].

Since the tariff would far outweigh the spending capacity of the users, it is subsidized with a cross-subsidy fund, the Social Electric Compensation Fund (FOSE). According to Law No. 27510 (established in 2001 and modified to include off-grid PV systems in 2010), the FOSE is a cross-subsidy administered by OSINERGMIN for poor households with a monthly energy consumption of below $100 \mathrm{kWh}$ [78]. The contributions for the cross-subsidy scheme are stemming from users with a monthly electricity consumption of above $100 \mathrm{kWh}$ (usually from urban areas). While different subsidy ranks are defined, the greatest subsidy (currently $77.5 \%$ ) is given to off-grid clients with an energy consumption of below $30 \mathrm{kWh}$ [79]. For example, the monthly tariff from a public EDC applied to a user with a system of $70 \mathrm{Wp}$ at the coastal lowlands amounts to S/.30.55 (about US\$10) per month, but the users ultimately pay only S/.6.25 (about US\$2) after applying the FOSE [80]. Tariffs are higher for users from private companies (S/.47.12 in total and S/.9.42 user contribution in this example) to compensate for the private company's initial investment [80].

The FOSE seems to make electricity affordable to rural populations. According to a RE researcher, the MEM had conducted a baseline study to capture the spending capacity of the poor rural households. This study revealed that even the poorest communities paid between 5 and 6 dollars per month on traditional energy (e.g., candles and kerosene) before receiving the RE solution. Nonetheless, default payment rates vary considerably: whereas Acciona Microenergía Peru's (AMPs) default rate is below $1 \%$, ADINELSA's rate varies between $15 \%$ and $40 \%$, and the EDC Electro Oriente (ELOR) reported an average of $51.56 \%$ in Iquitos [81-83]. Though the reasons for these differences are manifold and will be further discussed below, the default seems not to be due to an excessive user tariff. 


\subsubsection{Contribution to User Income}

Business users of Peruvian rural areas considered the availability of electricity to be essential for their businesses [84]. Still, rural electricity for productive uses have so far been limited to projects of grid expansion and some isolated pilot projects. However, there is huge potential for productive uses: e.g., fishing communities in the Amazon basin currently need to acquire ice for cooling the fishes in a city that is $3-4 \mathrm{~h}$ away, incurring high costs. A freezer running on electricity powered by PV systems could not only substantially lower these costs, but also assure the cold chain for the fishes. Moreover, increasing output from production would result in higher incomes of the rural population. Despite these opportunities, local governments often don't have the means to implement the projects. Interdisciplinary projects involving expertise from different disciplines and sectors are urgently needed to seize these opportunities.

The MIDIS was meant to assume this role; the Ministry was founded in 2010 to eradicate extreme poverty by coordinating different public organizations. The MIDIS administrates the Fund for Economic Inclusion in Rural Areas (FONIE), which was created in 2013 to finance interdisciplinary rural projects that attend needs for water and sanitation, electricity, local roads, and telecommunication [85]. However, the FONIE only provides the fund for the project implementation itself without any support to the community after the project implementation.

\subsection{Environmental Sustainability}

\subsubsection{Environmental Awareness}

Environmental awareness does not appear to be a priority for the Peruvian elite. Environmental measures that have been taken in this direction were mainly based on international pressure and the recent hosting of the Conference of the Parties (COP) 20 in 2014 in Lima. Although the creation of the Ministry of Environment (MINAM) in 2008 aimed to institutionalize environmental issues, the Ministry is still considered as emerging, mainly because it is lacking experts [86]. Despite the protection of forest resources by law, projects including huge deforestation have been approved [87]. In fact, the Worldbank revealed that, notwithstanding major environmental reforms between 2003 and 2009 , hardly any changes were registered concerning overfishing, deforestation, degradation of soil and water bodies caused by agriculture and mining, and poorly managed water resources [88].

According to some interviewees, the lack of environmental awareness is also apparent in the population's behaviour. For example, a study by McAllister [89] found that trash management became an issue in the community La Zaranda (Province of Ferreñafe in Northern Peru), as littering was a socially accepted practice. Indeed, despite the Environmental Education Project implemented in 2011 and the National Prize for Environmental Citizenship (2009), considerable challenges remain for environmentally responsible citizens [90]. In fact, the increase of socio-environmental conflicts arising from mining conflicts can hardly be associated with protesting against environmental impacts, but rather with a disconcert against the lacking social compensations from the mining industry (e.g., by creating jobs) [91].

\subsubsection{Environmental Impact}

In Peru, there are neither specific regulations nor any enforcement policies for rural electrification to mitigate critical environmental issues such as battery disposal. For instance, an examination in Cajamarca conducted by OSINERGMIN showed the devastating consequences of abandoned batteries [59]. There are exceptions, however; according to several interviewees, ADINELSA does have a policy on proper battery handling, as batteries are returned to Lima for recycling.

Therefore, various studies from international institutions urge the government of Peru to further substantiate environmental policies for rural electrification based on RE (see e.g., [61,92,93]). 


\subsection{Socio-Cultural Sustainability}

\subsubsection{Accessibility (Disparity, Equity)}

As pointed out above, access to electrification in rural areas has increased notably in Peru in recent years. Moreover, through the implementation of the "massive program", it is expected that other 150,000 households (in fact, as of December 2015, 190,000 systems were registered for installation; [81]) will get access to electricity for the first time. Although each of these households will receive systems of the same capacity (which appears to comply with a criterion of equity), the amount of energy supplied by the same off-grid PV systems in Amazon regions may be significantly lower than in the southern coastal lowlands [94]. Further disparities arise from the fact that the tariff depends on the EDC; users who are attended to by a private company have to pay more; e.g., in special Amazon regions, the tariff rises to S/.2.08 per kWh in the case of private EDCs, while it amounts to only S/1.26 per kWh in the Amazon basin and S/.1.39 per kWh in special Amazon regions [94].

Significant disparities in the access of energy affect the remote rural areas. Reaching these areas often requires trips of several hours by boat across the Amazon basin, and therefore they offer even less profits for EDCs. A representative of the MEM admitted that they don't properly attend to these regions in the FONER program, and they are not expected to be considered in the "massive program" either. Regarding the latter, the contract stipulates that Ergon (the tender bid winner) is expected to install the systems wherever it is "viable".

\subsubsection{Social Acceptance}

In general, the demand for access to electricity and the acceptance of off-grid PV solutions are both high in rural Peru. An Ergon representative declared that, as part of the "massive project", they had censored more than 150,000 dwellings, and none of the households has refused the offered off-grid PV system. Several interviewees mentioned the importance of modern communication technologies such as cell phones or computers, which have diffused even to the most remote parts of the country.

Nonetheless, the interaction between the community members and outsiders (e.g., representatives of EDCs) seems to have become problematic in areas where the mining industry is operating. According to a social researcher, the community usually holds a historically conflictive relationship with the companies. As discussed elsewhere (e.g., [91]), socio-environmental conflicts have indeed increased considerably in Peru.

These conflicts feed mistrust, which in turn appears to be related to default (that has plagued some off-grid PV projects by ELOR and ADINELSA). A representative from an NGO revealed that the level of mistrust due to conflicts with the mining industry have caused a loss of credibility also towards NGOs, such that gaining people's trust has been essential for reducing their current default rate to less than $1 \%$.

Based on these experiences, NGO-sponsored project managers and university researchers concurrently agreed on the importance of a participative approach, meaning that the local community is embedded in the project from the beginning. Unfortunately, this methodology is not used in government projects.

\subsubsection{Accuracy}

In order for a project to be accurate, it has to meet the specific local needs and consider the socio-cultural reality of each community. Unfortunately, it is not clear if Peruvian officials are widely aware of the need of accuracy. For example, ADINELSA deploys off-grid PV systems with capacities of either $50 \mathrm{Wp}$ or $85 \mathrm{Wp}$. The decision on the system capacity is based on the user's expenses for alternative energy sources (such as candles, kerosene) before electrification. The limited capacity of ADINELSA solutions has been criticized, since it was not defined according to community-specific energy needs; the EDC, however, argues that higher capacity may be too expensive for some households (as the tariff depends on the capacity). 
In the "massive program", Ergon will install $120 \mathrm{Wp}$ systems everywhere regardless of the user's habits of its region. A MEM representative and a high ranking official agreed that ideally the capacity of the systems would have been defined according to the real needs and the income level determined in a baseline analysis of each community and pursuant to the different local, cultural, and geographical circumstances. However, this has not been done to save costs.

\subsubsection{Cultural Justice}

Peru is culturally extremely diverse, with multiple indigenous communities living across the country. Besides gender issues and language differences, there is diversity in the community organization and the willingness to participate in projects. However, culture has mostly been neglected in the public sector. Although the request for tenders of the "massive program" stipulated that "[t]he Investor will design the autonomous RER [Renewable Energy Resources] installations taking into consideration the background and the social economic characteristics of the user" [58], there are no specific indications (except for translating system handbooks to indigenous languages) of how this should be put into practice.

The disregard of socio-cultural particularities of rural communities has also been reported regarding the role of women in rural electrification, who were found to hardly participate in the projects. This deficiency in socio-cultural aspects has led to project failures or payment defaults. The EDCs tend to attribute these defaults to an excessive price, or to the users' unwillingness to pay. However, in NGO-sponsored projects that have succeeded in engaging the community, the default rate is much lower.

\subsection{Summary of the Results}

The analysis presented in this section has shown that Peru is quite strong in the economic sustainability dimension, while significant weaknesses became evident particularly in the institutional and socio-cultural dimension, which has in turn negative implications for the environmental dimension of sustainability. For each sustainability indicator considered in this paper, Table 4 provides a summary of the strengths and weaknesses of rural electrification efforts in Peru based on off-grid PV solutions. Based on the results, some conclusions will be drawn in the following section.

Table 4. Strengths and weaknesses of rural electrification efforts in Peru based on off-grid PV solutions.

\begin{tabular}{|c|c|c|}
\hline Indicator & Strength & Weaknesses \\
\hline Stability & & Frequent rotation of high-ranking officials. \\
\hline \multirow{4}{*}{ Regulation and Standards } & \multirow{4}{*}{$\begin{array}{l}\text { Technical standards and regulations have } \\
\text { been defined. }\end{array}$} & Adopted technical standards are obsolete. \\
\hline & & $\begin{array}{l}\text { The regulatory framework does not } \\
\text { consider some technologies (e.g., SPS or } \\
\text { micro-grids), which avoids their adoption. }\end{array}$ \\
\hline & & No service standards have been adopted. \\
\hline & & $\begin{array}{l}\text { Neither adopted standards nor regulations } \\
\text { are enforced. }\end{array}$ \\
\hline \multirow[t]{2}{*}{$\begin{array}{l}\text { Decentralization and Openness } \\
\text { to participation }\end{array}$} & \multirow{2}{*}{$\begin{array}{l}\text { Decentralization efforts have been } \\
\text { conducted, including budget allocation to } \\
\text { local governments (i.e., municipalities). }\end{array}$} & $\begin{array}{l}\text { Lack of technical know-how at local level } \\
\text { (i.e., municipalities), which has resulted in } \\
\text { failure of municipality-sponsored projects. }\end{array}$ \\
\hline & & $\begin{array}{l}\text { No interaction or coordination between } \\
\text { different sectors, institutions or } \\
\text { government levels. }\end{array}$ \\
\hline \multirow{3}{*}{$\begin{array}{l}\text { Adaptability (ability to meet } \\
\text { future needs) }\end{array}$} & & $\begin{array}{l}\text { Duplicity of agencies with overlapping } \\
\text { competences and responsibilities. }\end{array}$ \\
\hline & & $\begin{array}{l}\text { Peru lacks a single decentralized agency for } \\
\text { overseeing off-grid electrification programs. }\end{array}$ \\
\hline & & $\begin{array}{l}\text { Widespread outsourcing with weak quality } \\
\text { controls by regulators or EDCs. }\end{array}$ \\
\hline
\end{tabular}


Table 4. Cont.

\begin{tabular}{|c|c|c|}
\hline Indicator & Strength & Weaknesses \\
\hline \multirow[t]{2}{*}{ Affordability } & $\begin{array}{l}\text { Cross subsidies for subsidizing rural } \\
\text { electrification efforts. }\end{array}$ & \\
\hline & $\begin{array}{l}\text { Adequate tariff scheme for users of off-grid } \\
\text { PV systems. Tariff is below previous } \\
\text { expenditures on traditional fuels } \\
\text { like candles. }\end{array}$ & \\
\hline Cost effectiveness & $\begin{array}{l}\text { Official have recognized that off-grid PV } \\
\text { systems are a cost-effective alternative to } \\
\text { grid expansion. They have also recognized } \\
\text { the advantages of economies of scale in the } \\
\text { case of stand-alones PV solutions. }\end{array}$ & \\
\hline $\begin{array}{l}\text { Consideration of operation and } \\
\text { maintenance costs }\end{array}$ & $\begin{array}{l}\text { Costs, tariffs, and subsidies have been } \\
\text { calculated considering both the initial costs } \\
\text { and the O\&M costs by using a } \\
\text { sophisticated model. }\end{array}$ & $\begin{array}{l}\text { The O\&M costs (and subsequently tariffs } \\
\text { and subsidies) may still be underestimated } \\
\text { by not properly considering geographical } \\
\text { differences between regions. }\end{array}$ \\
\hline Contribution to income of users & $\begin{array}{l}\text { Enormous potential for productive use (e.g., } \\
\text { refrigerating fresh fish). }\end{array}$ & $\begin{array}{l}\text { Productive use has only been considered in } \\
\text { electrification projects based on the } \\
\text { grid-expansions. }\end{array}$ \\
\hline Reliability of supply & & $\begin{array}{l}\text { The lack of spare parts/maintenance of } \\
\text { off-grid PV systems in rural areas has } \\
\text { caused high failure rates. }\end{array}$ \\
\hline Environmental awareness & $\begin{array}{l}\text { Rural populations (especially in areas } \\
\text { where mining is intensive and has caused } \\
\text { externalities) have developed a notion of } \\
\text { environmental awareness. }\end{array}$ & $\begin{array}{l}\text { Environmental awareness is not } \\
\text { widespread in the Peruvian elite. } \\
\text { Environmental measures appear to be } \\
\text { mainly based on international pressure, but } \\
\text { the mining activities for example are } \\
\text { subjected to few and weak } \\
\text { environmental regulations. }\end{array}$ \\
\hline Environmental impact & $\begin{array}{l}\text { The National Evaluation System of the } \\
\text { Environmental Impact also applies for rural } \\
\text { electrification. }\end{array}$ & $\begin{array}{l}\text { The lack of specific regulations and } \\
\text { enforcement policies on environmental } \\
\text { hazards has resulted in negative } \\
\text { environmental impacts such as } \\
\text { abandoned batteries. }\end{array}$ \\
\hline \multirow[t]{2}{*}{ Accessibility (disparity, equity) } & \multirow{2}{*}{$\begin{array}{l}\text { Cross subsidy tariff scheme as well as } \\
\text { initiatives (such as the "massive program"), } \\
\text { demonstrate the willingness of the Peruvian } \\
\text { elite to ensure access to electricity. }\end{array}$} & $\begin{array}{l}\text { EDCs and regulators have shown little } \\
\text { interest in providing electricity to } \\
\text { inhabitants of remote areas. }\end{array}$ \\
\hline & & $\begin{array}{l}\text { Disparities between regions (price } \\
\text { per } \mathrm{kWh} \text { ). }\end{array}$ \\
\hline Accuracy & & $\begin{array}{l}\text { System capacity is determined by its } \\
\text { affordability rather than in the needs of the } \\
\text { populations. As a consequence, systems } \\
\text { often fell short of energy demand. }\end{array}$ \\
\hline Social acceptance & & $\begin{array}{l}\text { There is a significant mistrust between the } \\
\text { government and rural population } \\
\text { (especially in areas where mining is } \\
\text { extensive). This conflictive relationship } \\
\text { jeopardizes social acceptance of } \\
\text { electrification projects and may result in the } \\
\text { rejection of the PV systems. }\end{array}$ \\
\hline Cultural Justice & & $\begin{array}{l}\text { MEM projects are designed without the } \\
\text { engagement of the community, as Peruvian } \\
\text { officials appear to be unaware of the } \\
\text { importance of local participation. }\end{array}$ \\
\hline
\end{tabular}

Source: Own elaboration.

\section{Conclusions}

In this paper, we assess the sustainability of rural electrification programs in Peru, paying special attention to the "massive program" (that aims to deploy a minimum of 150,000 off-grid PV solutions in the upcoming years). Our assessment was based on a set of indicators corresponding to the four dimensions of sustainability considered in this paper: institutional, economic, environmental, and socio-cultural. 
The sustainability of rural electrification programs demands for strong formal institutions with a flexible and decentralized structure. However, we found that the organization of the MEM/DGER hardly meets these criteria. Two agencies (DFC and DPR) both under the MEM/DGER, currently conduct off-grid PV projects for rural electrification. Competences of both agencies (DFC and DPR) appear to be overlapping, which has caused rivalry between them. Moreover, steady staff rotation has caused disturbing changes in the regulatory framework of Peru; this instability has inhibited following a strategic line in rural electrification as projected by the PNER.

Drawbacks in the Peruvian decentralization process have significantly affected prior rural electrification efforts. Decentralization (understood as redistribution of the funds to elected local governments) has allowed local or regional governments to implement electrification projects by themselves. However, these projects have been rarely successful, since the capacities on the regional and local scale on RE projects are basically non-existent. Moreover, the MEM is centrally designing its projects without the participation of those who are closest to the community. Indeed, the role of the rural communities in Peru is limited and they are normally not involved in the design and implementation of projects sponsored by the government.

Despite the country's huge potential for systems for productive uses that increase the user's income, these kind of solutions have not been considered so far. This is due to a lack of basic skills and know-how of the rural population on the opportunities and uses of energy as well as on business know-how in general. Interdisciplinary programs (e.g., including drinking water and sanitation, roads, education, etc.) could help with assessing this gap, but recent attempts by MIDIS have fallen behind expectations. This inhibits seizing opportunities regarding productive uses of off-grid PV systems.

Widespread outsourcing as currently occurring in Peru (in rural electrification, off-grid PV system installations and O\&M of off-grid PV system are outsourced) requires strong quality control. However, the technical standards for off-grid PV systems are not up to date, while service standards do not exist in Peru. As a consequence, the reliability of off-grid PV systems has been an issue in Peru, especially regarding O\&M.

Cross subsidies for subsidizing rural electrification efforts have facilitated a notable increase in the electrification rate of the country in recent years. However, system capacity is determined by its affordability rather than by the needs of the populations. As a consequence, systems often fell short of energy demand. Although some adaptations of the tariff model should be considered (especially regarding tariff equity between regions/between private and public EDCs), we found that the tariff scheme has made off-grid PV systems affordable for users (the tariff is below previous expenditures on traditional fuels like candles).

We also found that MEM projects are still designed without considering the fact that Peru is culturally diverse, which has often led to payment defaults, especially in projects sponsored by the government that failed in engaging the community. Indeed, Peruvian officials often appear to be unaware of the importance of local participation (as local values and lifestyles are disregarded), and there is a significant mistrust between the government and the rural population (especially in areas where mining is extensive).

Environmental awareness is not yet an issue for the majority of the Peruvian elite, such that overfishing, deforestation, and degradation of soil and water bodies caused by agriculture and mining are frequent. Although communities affected by these problems show early signs of the awakening of environmental awareness, we found that there are neither specific regulations nor any enforcement policies aimed at the mitigation of critical environmental issues associated with off-grid PV systems (such as battery disposal).

As the Peruvian case revealed, assuring the sustainability of the off-grid PV systems cannot be achieved by only providing funds for the initial investment and the O\&M. Indeed, the high number of inoperative systems in some of Peru's programs is a strong indicator for their unsustainability. Attention must be paid to the other dimension of the sustainability (environmental, socio-cultural and institutional). We expect that our conclusions may help Peruvian institutions to address the most 
severe drawbacks affecting their rural electrification efforts, particularly those that can compromise the sustainability of the ongoing "massive program".

Author Contributions: The first author conceptualized and structured the paper. The first author was solely responsible for data collection (interviews) and analysis. The whole paper was jointly drafted and developed by the authors to bring to the current state.

Funding: This research received no external funding.

Acknowledgments: The support of CORFO (Preis 14BPC4-28651, 15BP-45364, 16BPE2-66227, and 17BPE-73748), CONICYT-ANILLO ACT1410, and FONDECYT (Preis 1151034) is gratefully acknowledged.

Conflicts of Interest: The authors declare no conflict of interest.

\section{References}

1. Ministerio de Energía y Minas (MEM). Plan Nacional De Electrificacion Rural (PNER) Periodo 2016-2025; Dirección General de Electrificación Rural: Lima, Peru, 2015. (In Spanish)

2. Ministerio de Energía y Minas (MEM). Proyecto De Mejoramiento de la Electrificación Rural mediante la aplicación de Fondos Concursables II (FONER II); Manual de Operaciones del Proyecto; Reviewed August 2015; Dirección General de Electrificación Rural: Lima, Peru, 2011. (In Spanish)

3. Bernhardt, J. The Effectiveness of Science-Policy Interactions: Case Studies on Climate Change Mitigation and Sustainable Development in Pan-European Forest Research and Politics. Ph.D. Thesis, Univerity of Hamburg, Hamburg, Germany, 2015.

4. Heinrichs, H.; Laws, N. "Sustainability State" in the Making? Institutionalization of Sustainability in German Federal Policy Making. Sustainability 2014, 6, 2623-2641. [CrossRef]

5. Nguyen-Trinh, H.A.; Ha-Duong, M. Perspective of $\mathrm{CO}_{2}$ capture \& storage (CCS) development in Vietnam: Results from expert interviews. Int. J. Greenh. Gas Control 2015, 37, 220-227.

6. Hugé, J.; Mukherjee, N.; Fertel, C.; Waaub, J.P.; Block, T.; Waas, T.; Dahdouh-Guebas, F. Conceptualizing the effectiveness of sustainability assessment in development cooperation. Sustainability 2015, 7, 5735-5751. [CrossRef]

7. Feron, S.; Heinrichs, H.; Cordero, R.R. Are the Rural Electrification Efforts in the Ecuadorian Amazon Sustainable? Sustainability 2016, 8, 443. [CrossRef]

8. Ilskog, E. Rural electrification sustainability indicators-Manual for field workers. 2008. Available online: http://swepub.kb.se/bib/swepub:oai:DiVA.org:kth-9132?tab2=abs\&language=en (accessed on 27 June 2014).

9. Derakhshan, F. On Sustainability in Local Energy Planning. Ph.D. Thesis, Lund University, Lund, Sweden, 2011.

10. Sharma, T.; Balachandra, P. Benchmarking sustainability of Indian electricity system: An indicator approach. Appl. Energy 2015, 142, 206-220. [CrossRef]

11. Wimmler, C.; Hejazi, G.; de Oliveira Fernandes, E.; Moreira, C.; Connors, S. Multi-Criteria Decision Support Methods for Renewable Energy Systems on Islands. JOCET 2015, 3, 186-195. [CrossRef]

12. Reddy, B.S. Measuring and Evaluating Energy Security and Sustainability: A Case Study of India; Indira Gandhi Institute of Development Research: Mumbai, India, 2015.

13. Gollwitzer, L. Community-Based Micro Grids: A Common Property Resource Problem; STEPS Working Paper 68; STEPS Centre: Sussex, UK, 2014; ISBN 978-1-78118-192-8.

14. Retnanestri, M. The I3A Framework-Enhancing the Sustainability of Off-Grid Photovoltaic Energy Service Delivery in Indonesia. Ph.D. Thesis, University of New South Wales (UNSW), Sydney, Australia, 2007.

15. Frame, D.; Tembo, K.; Dolan, M.J.; Strachan, S.M.; Ault, G.W. A community based approach for sustainable off-grid PV systems in developing countries. In Proceedings of the Power and Energy Society General Meeting, San Diego, CA, USA, 24-29 July 2011.

16. Holland, R.; Perera, L.; Sanchez, T.; Wilkinson, R. Decentralised rural electrification: Critical success factors and experiences of an NGO. Refocus 2001, 2, 28-31. [CrossRef] 
17. Sims, R.E.H.; Schock, R.N.; Adegbululgbe, A.; Fenhann, J.; Konstantinaviciute, I.; Moomaw, W.; Nimir, H.B.; Schlamadinger, B.; Torres-Martínez, J.; Turner, C.; et al. Energy supply. In Climate Change 2007: Mitigation. Contribution of Working Group III to the Fourth Assessment Report of the Intergovernmental Panel on Climate Change; Metz, B., Davidson, O.R., Bosch, P.R., Dave, R., Meyer, L.A., Eds.; Cambridge University Press: Cambridge, UK; New York, NY, USA, 2007.

18. Fischedick, M.; Borbonus, S.; Scheck, H. Towards Global Energy Governance-Strategies for Equitable Access to Sustainable Energy; Policy Paper; Development and Peace Foundation: Bonn, Germany, 2011.

19. Brent, A.C.; Rogers, D.E. Renewable rural electrification: Sustainability assessment of mini-hybrid off-grid technological systems in the African context. Renew. Energy 2010, 35, 257-265. [CrossRef]

20. Mainali, B.; Pachauri, S.; Rao, N.D.; Silveira, S. Assessing rural energy sustainability in developing countries. Energy Sustain. Dev. 2014, 19, 15-28. [CrossRef]

21. Mainali, B. Sustainability of Rural Energy Access in Developing Countries. Ph.D. Thesis, KTH Royal Institute of Technology, Stockholm, Sweden, 2014.

22. Dincer, I.; Acar, C. A review on clean energy solutions for better sustainability. Int. J. Energy Res. 2015, 39, 585-606. [CrossRef]

23. Dunmade, I. Indicators of sustainability: Assessing the suitability of a foreign technology for a developing economy. Technol. Soc. 2002, 24, 461-471. [CrossRef]

24. Cook, P. Infrastructure, rural electrification and development. Energy Sustain. Dev. 2011, 15, $304-313$. [CrossRef]

25. Khandker, S.R.; Barnes, D.F.; Samad, H.A. Welfare impacts of rural electrification: A panel data analysis from Vietnam. Econ. Dev. Cult. Chang. 2013, 61, 659-692. [CrossRef]

26. Garniati, L.; Owen, A.; Kruijsen, J.; Ishadamy, Y.; Wibisono, I. Interface between appropriate technology and sustainable energy policy in vulnerable societies. Sustain. Cities Soc. 2014, 12, 9-15. [CrossRef]

27. Chaurey, A.; Kandpal, T.C. Assessment and evaluation of PV based decentralized rural electrification: An overview. Renew. Sust. Energy Rev. 2010, 14, 2266-2278. [CrossRef]

28. Stringer, L.C.; Paavola, J. Participation in environmental conservation and protected area management in Romania: A review of three case studies. Environ. Conserv. 2013, 40, 138-146. [CrossRef]

29. Rickerson, W.; Uppal, J.; Glassmire, J.; Lilienthal, P.; Sanders, E.; Colson, C.; Couture, T. Renewable Energies for Remote Areas and Islands (REMOTE); International Energy Agency-Renewable Energy Technology Deployment (IEA-RETD): Paris, France, 2012.

30. Vera, I.A.; Langlois, L.M.; Rogner, H.H.; Jalal, A.I.; Toth, F.L. Indicators for sustainable energy development: An initiative by the International Atomic Energy Agency. In Natural Resources Forum; Blackwell Publishing Ltd.: Hoboken, NJ, USA, 2005; Volume 29, pp. 274-283.

31. Polack, A. Drivers and barriers of renewable energy in the electrification of Vanuatu. Ph.D. Thesis, Murdoch University, Murdoch, Australia, 2010.

32. Rosen, M.A. Energy sustainability: A pragmatic approach and illustrations. Sustainability 2009, 1, 55-80. [CrossRef]

33. Bhattacharyya, S.C. Energy access programmes and sustainable development: A critical review and analysis. Energy Sustain. Dev. 2012, 16, 260-271. [CrossRef]

34. Ribeiro, F.; Ferreira, P.; Araújo, M. The inclusion of social aspects in power planning. Renew. Sustain. Energy Rev. 2011, 15, 4361-4369. [CrossRef]

35. Fenner, R.A.; Ainger, C.M.; Cruickshank, H.J.; Guthrie, P.M. Widening engineering horizons: Addressing the complexity of sustainable development. Proc. ICE-Eng. Sustain. 2006, 159, 145-154. [CrossRef]

36. Ritchie, J.; Lewis, J.; Nicholls, C.M.; Ormston, R. Qualitative Research Practice: A Guide for Social Science Students and Researchers; Sage: London, UK, 2013.

37. MAXQDA. Software for Qualitative Data Analysis, 1989-2018; VERBI Software-Consult-Sozialforschung GmbH: Berlin, Germany, 2018.

38. Hall, A.L.; Rist, R.C. Integrating multiple qualitative research methods (or avoiding the precariousness of a one-legged stool). Psychol. Mark. 1999, 16, 291-304. [CrossRef]

39. Instituto Nacional de Estadistica e Informatica (INEI). Día Mundial de la Poblacion. 2015. Available online: https:/ / www.inei.gob.pe/media/MenuRecursivo/publicaciones_digitales/Est/Lib1251/Libro.pdf (accessed on 15 November 2016). (In Spanish) 
40. Worldbank. World Development Indicators, NA. Available online: http://databank.bancomundial.org. (accessed on 28 January 2016).

41. Instituto Nacional de Estadistica e Informatica (INEI). Población en Situación de Pobreza Monetaria, según Ámbito Geográfico, 2004-2014. NA. Available online: https: / / www.inei.gob.pe/estadisticas/indicetematico/sociales / (accessed on 28 January 2016). (In Spanish)

42. Instituto para la Democracia y la Asistencia Electoral (IDEA). Estado: Funcionamiento; Organización y Proceso De Construcción De Políticas Públicas: Lima, Peru, 2008. (In Spanish)

43. Damonte, G.; Fuller, N.; Valcárcel, M. Minería, Turismo y Agroindustria: Nuevos Ejes Económicos; Departamento de Ciencias Sociales, Pontificia Universidad Católica del Perú: Lima, Peru, 2009. (In Spanish)

44. La Contraloría General de la República. Estudio del Proceso de Descentralización en el Perú; Contraloría General de la República: Lima, Peru, 2014. (In Spanish)

45. Ministerio de Economia y Finanzas (MEF) Proyecto de Presupuesto. Anexo 2. NA. Available online: https: / / www.mef.gob.pe/index.php?option=com_content\&view=article\&id=4129\&Itemid=101156\& lang=es (accessed on 29 January 2016). (In Spanish)

46. Torero, M.; Pascó-Font, A. The Social Impact of Privatization and the Regulation of Utilities in Peru; Discussion Paper 2001/017; UNU-WIDER: Helsinki, Finland, 2001.

47. Ruiz-Caro, A. El Proceso de Privatizaciones en el Perú Durante el Período 1991-2001 (Vol. 22); United Nations Publications: Santiago de Chile, Chile, 2002. (In Spanish)

48. Organismo Supervisor de la Inversión en Energía y Minería (OSINERGMIN) (NA). Available online: http:/ / www.osinergmin.gob.pe (accessed on 31 January 2016). (In Spanish)

49. Ministerio de Energía y Minas (MEM). Directorio de las Empresas del Subsector Eléctrico, NA. Available online: http:/ / www.minem.gob.pe/_detalle.php?idSector=6\&idTitular=6143\&idMenu=sub113\& idCateg=1039 (accessed on 30 September 2016). (In Spanish)

50. Ministerio de Energía y Minas (MEM). Normatividad Electrica. Ley de Concesiones Eléctricas y Reglamento Decreto Ley $N^{\circ} 25844$ y Decreto Supremo No 009-93-EM Ley Para Asegurar el Desarrollo Eficiente de la Generación Eléctrica y Reglamentos Ley $N^{\circ}$ 28832; Diario Oficial El Peruano: Lima, Peru, 2014. (In Spanish)

51. Congreso de la Republica. Ley General de Electrificación Rural LEY No 28749; Diario Oficial El Peruano: Lima, Peru, 2006. (In Spanish)

52. International Renewable Energy Agency (IRENA). Renewable Energy in Latin America 2015: An Overview of Policies. 2015. Available online: http:/ / www.irena.org/publications/2015/Jun/Renewable-Energy-inLatin-America-2015-An-Overview-of-Policies (accessed on 13 May 2018).

53. Ministerio de Economia y Finanzas (MEF). Banco de Proyectos SNIP, NAb. Available online: http:/ / www.mef.gob.pe/contenidos/inv_publica/new-bp/operaciones-bp.php (accessed on 4 February 2016). (In Spanish)

54. Ministerio de Energía y Minas (MEM). Banco Mundial. Mejoramiento de la Electrificación Rural Mediante La Aplicación de Fondos Concursables. Estudio de Preinversión a nivel de Pre - Factibilidad; Ministerio de Energía y Minas: Lima, Peru, 2005. (In Spanish)

55. Defensoría del Pueblo. La Electrificación Rural en el Perú: Derechos y Desarrollo para Todos. Informe Defensorial No 149. Biblioteca Nacional del Perú: No 2010-04176; Biblioteca Nacional: Lima, Peru, 2010. (In Spanish)

56. Ministerio de Energía y Minas (MEM). Plan Nacional De Electrificacion Rural (PNER) Periodo $2013-2022$. 2012. Available online: http:/ / dger.minem.gob.pe/ArchivosDger/PNER_2013-2022/PNER-2013-2022\% 20Texto.pdf (accessed on 30 June 2016). (In Spanish)

57. Organismo Supervisor de la Inversión en Energía y Minería (OSINERGMIN). Tender Documents for Auction of Electricity Supply with Renewable Energy Resources in Areas Not Connected to Network. 2014. Available online: http:/ / www2.osinerg.gob.pe/EnergiasRenovables/contenido/1eraSubastaOffGrid. Bases.html (accessed on 1 February 2016).

58. Jané La Torre, E.; Palacios, D. Estado Situacional De La Prestación del Servicio Electrico Mediante Sistemas Fotovoltaicos Autónomos; Gerencia de Fiscalización Eléctrica, Osinergmin: Lima, Peru, 2015. (In Spanish)

59. Van der Akker, H.A. Electrificación Rural a base de Energía Fotovoltaica en el Perú-Proyecto PER/98/G31; Advisory Services on Climate, Energy and Development Issues (Ascendis): Loveren, The Netherlands, 2008. (In Spanish) 
60. Agencia de Cooperación Internacional de Japón (JICA). Estudio del Plan Maestro de Electrificación Rural con Energía Renovable en la República del Perú. Informe Final Resumen Ejecutivo; 2008. Available online: http:/ / open_jicareport.jica.go.jp/pdf/11893203.pdf (accessed on 7 April 2017). (In Spanish)

61. United Nations Development Program (UNDP); Global Environment Facility (GEF). Analisis De Programas Y Modelos De Gestión En Electrificación Rural Aplicados En Latinoamerica y El Mundo y Propuestas de Modelos de Aplicación Nacional. Proyoecto PER/98/G31, Electrificación Rural a base de Energía Fotovoltaica en el Perú. 2006. Available online: http://dger.minem.gob.pe/archivos/309_Inf_ ProgNacionales.pdf (accessed on 15 June 2016). (In Spanish)

62. JanéLa Torre, E.; Palacios, D. Resultados De La Supervisión A Sistemas Eléctricos Rurales Aislados a Cargo De Municipalidades y Entidades Locales 2008-2010; Documento de Trabajo No 26-GFE; Gerencia de Fiscalización Eléctrica, Osinergmin: Lima, Peru, 2011. (In Spanish)

63. Canessa, R.; Santome, J.M.; Buss, I.N. Evaluación Ex Post Del Programa Euro-Solar. Informe Final Contrato Específico N²013/332211. 2014. Available online: https:/ / ec.europa.eu/europeaid/sites/devco/files / eurosolar-informe-final_es.pdf (accessed on 3 July 2016). (In Spanish)

64. Fernandez, M. Experiencias con Sistemas Fotovoltaicos de Tercera Generacion en Argentina, Bolivia y Peru; ESMAP, Worldbank: Washington, DC, USA, 2015. (In Spanish)

65. Verástegui Gubler, A.; Moreno Morales, A.I.; Cordero Torres, V. Evaluación en campo de funcionamiento, aceptación e impactos de sistemas pico fotovoltaicos en la región San Martín. Deutsche Gesellschaft für Internationale Zusammenarbeit, NA. Available online: https:/ / energypedia.info/images/1/1a/Primeras_ experiencias_de_sistemas_pico_PV_en_el_Perú.pdf (accessed on 18 October 2016). (In Spanish)

66. PrialéUgás, M. Sistematización del Proyecto: “Evaluación integral para la promoción de fuentes de energía renovables, como alternativa para mejorar la calidad de vida de poblaciones aisladas de la Amazonía en América Latina. Informe Final.". Soluciones Practicas, EUEI. 2012. Available online: http://www.eueipdf.org/sites/default/files/field_publication_file/EUEI_PDF_Informe_final_Jan2015_ES.pdf (accessed on 4 December 2016). (In Spanish)

67. Horn, M. Solar Photovoltaics for Sustainable Rural Electrification in Developing Countries: The Experiences in Peru; Universidad Nacional de Ingeniería-Centro de Energías Renovables: Lima, Peru, 2003.

68. Egido, M.A.; Vega, P.; Horn, M.J. Field Evaluation of A PV Rural Electrification Project In A Titicaca Lake Island. In Proceedings of the 19th European Photovoltaic Solar Energy Conference, Paris, France, 7-11 June 2004.

69. Arráiz, I.; Calero, C. From Candles to Light: The Impact of Rural Electrification. Inter-American Development Bank, 2015. Available online: https:/ / publications.iadb.org/handle/11319/6917 (accessed on 19 February 2017).

70. Magill, J.O.; Valdés, J.E. "Acceso Universal A La Electricidad" ... ¿ Y Perú? XVIII Simposio Peruano de Energía Solar y del Ambiente (XVIII-SPES): Lima, Peru, 2011. (In Spanish)

71. ACCIONA Microenergía Perú (AMP) Fundación Acciona Microenergía, NA. Available online: http://www. acciona.com/es/sostenibilidad/sociedad/fundacion-acciona-microenergia/ (accessed on 12 July 2016).

72. Pyhala, A. Institutions, Participation, and Protected Area Management in Western Amazonia. In Commons in an Age of Globalisation; The Ninth Conference of the International Association for the Study of Common Property: Victoria Falls, Zimbabwe, 2002; pp. 17-21.

73. Thoenig, J.C. Territorial institutions. In The Oxford Handbook of Political Institutions; Rhodes, R.A., Binder, S.A., Rockman, B.A., Eds.; Oxford University Press: Oxford, UK, 2008; pp. 281-302.

74. International Energy Agency (IEA). Pico Solar PV Systems for Remote Homes. A New Generation of Small PV Systems for Lighting and Communication". 2013. Available online: http:/ / www.iea-pvps.org/fileadmin/

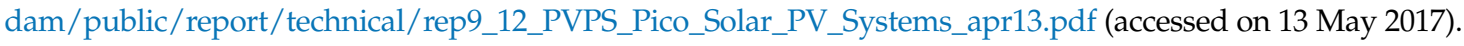

75. Ramos Rivas, R. (Subasta De Suministro de Electricidad con Recursos Energeticos Renovables en Areas no Conectadas a Red. 2014. Available online: http:/ / webcache.googleusercontent.com/search?q=cache: 1OucQ96Vxh0J:www2.osinerg.gob.pe/EnergiasRenovables/contenido/Documentos/1SubastaOffGrid/ Actas / Acta \%2520de\%2520Adjudicacion\%2520Buena\%2520Pro.pdf +\&cd=1\&hl=en\&ct=clnk\&gl=us\& client=safari (accessed on 4 August 2016). (In Spanish)

76. Organismo Supervisor de la Inversión en Energía y Minería (OSINERGMIN). Resolución Del Consejo Directivo Organismo Supervisor De La Inversión en Energía y Mineria OSINERGMIN N 139-2016-OS/CD, 2016a. Available online: http:/ / www2.osinerg.gob.pe/Resoluciones/pdf/2016/OSINERGMIN\%20No.1402016-OS-CD.pdf (accessed on 28 June 2016). (In Spanish) 
77. Organismo Supervisor de la Inversión en Energía y Minería (OSINERGMIN). Resolución De Consejo Directivo $N^{\circ}$ 235-2010-OS/CD; OSINERGMIN: Lima, Peru, 2010. (In Spanish)

78. Congreso de Perú. Proyecto de Ley No. 3466/2013-CR; Diario Oficial El Peruano: Lima, Peru, 2013. (In Spanish)

79. Organismo Supervisor de la Inversión en Energía y Minería (OSINERGMIN). Fijación de la Tarifa Rural para Sistemas Fotovoltaicos 2014-2018. Publicación del Proyecto de Resolución. Expediente N 0248-2014-GART; OSINERGMIN: Lima, Peru, 2014. (In Spanish)

80. Organismo Supervisor de la Inversión en Energía y Minería (OSINERGMIN). Informe No 403-2014-GART Informe legal sobre la procedencia de aprobar la Resolución que fija la Tarifa Eléctrica Rural para Suministros no Convencionales (Sistemas Fotovoltaicos); OSINERGMIN: Lima, Peru, 2014. (In Spanish)

81. Jáuregui Chinchay, J. Materiales Necesarios Para La Operación, Mantenimiento Y Gestión Comercial De Los Sistemas Fotovoltaicos Domiciliarios En Los Distritos De Indiana, Mazan Y Las Amazona. Informe Ejecutivo N Gc-032-2014; OSINERGMIN: Lima, Peru, 2014. (In Spanish)

82. ACCIONA Microenergía Perú (AMP). Luz en Casa. Acceso A Energía Sostenible En Comunidades Rurales De Perú; Centro de Innovación en Tecnología para el Desarrollo Humano - itdUPM: Madrid, Spain, 2014. (In Spanish)

83. Yadoo, A. Delivery Models for Decentralised Rural Electrification: Case Studies in Nepal, Peru and Kenya; International Institute for Environment and Development: London, UK, 2012.

84. Ministerio de Desarrollo e Inclusion Social (MIDIS). Manual de Operaciones Fondo para la Inclusión Económica en Zonas Rurales (FONIE). 2013. Available online: http:/ /www.midis.gob.pe/index.php/es/ fonie-anexos-formatos (accessed on 25 March 2017). (In Spanish)

85. Lanegra, I. Institucionalidad ambiental peruana. In Agenda de Investigación en Temas Socioambientales en el Perú: Una Aproximación Desde las Ciencias Sociales; CISEPA-PUCP INTE, Facultad de Ciencias Sociales GEA: Lima, Peru, 2014. (In Spanish)

86. Environmental Investigation Agency (EIA). Deforestation by Definition: The Peruvian Government Fails to Define Forests as Forests, while the Malaysian Influence and Palm Oil Expansion Threaten the Amazon; EIA: Washington, DC, USA, 2015.

87. Liebenthal, A.; Salvemini, D. Promoting Environmental Sustainability in Peru: A Review of the World Bank Group's Experience (2003-2009); IEG Working paper 2011/1; World Bank: Washington, DC, USA, 2011.

88. McAllister, J. Factors Influencing Solid-Waste Management in the Developing World. All Graduate Plan B and Other Reports. Master's Thesis, Utah State University, Logan, UT, USA, 2015.

89. United Nations Economic Commission for Latin America and the Caribbean (ECLAC); Organisation for Economic Cooperation and Development (OECD). Environmental Performance Reviews Peru. Highlights and recommendations. 2016. Available online: https:/ / www.oecd.org/environment/country-reviews/1600312-environmental\%20performance\%20review-peru-web.pdf (accessed on 12 September 2016).

90. Paredes, M.; de la Puente, L. Protestas y negociaciones socioambientales. El caso de las industrias extractivas. In Agenda de Investigación en Temas Socioambientales en el Perú. Una Aproximación Desde las Ciencias Sociales; CISEPA-PUCP INTE, Facultad de Ciencias Sociales; GEA: Lima, Peru, 2014. (In Spanish)

91. Ministerio de Energía y Minas (MEM). Guia De Instalación De Sistemas Fotovoltaicos Domésticos (SFD). 2007. Available online: http:/ / www.minem.gob.pe/minem/archivos/file/Electricidad/eficiencia\%20energetica/ guia\%20de\%20instalacion\%20de\%20sistemas\%20fotovoltaicos\%20dom.pdf (accessed on 3 April 2017). (In Spanish)

92. Olano, M.E. Marco De Evaluación De Impactos Ambientales Para El Proyecto De Electrificación Rural En El Perú; Ministerio de Energía y Minas: Lima, Peru, 2005. (In Spanish)

93. Organismo Supervisor de la Inversión en Energía y Minería (OSINERGMIN). Tarifa Eléctrica Rural para Sistemas Fotovoltaicos (Vigente a partir del 04/ene/2016). 2016. Available online: http:/ / www2.osinerg. gob.pe/Tarifas/pdfsTarifas/TFBT8_04012016.pdf (accessed on 8 May 2016). (In Spanish)

94. Lillo, P.; Ferrer-Martí, L.; Boni, A.; Fernández-Baldor, A. Assessing management models for off-grid renewable energy electrification projects using the human development approach: Case study in Peru. Energy Sustain. Dev. 2015, 25, 17-26. [CrossRef]

(C) 2018 by the authors. Licensee MDPI, Basel, Switzerland. This article is an open access article distributed under the terms and conditions of the Creative Commons Attribution (CC BY) license (http:/ / creativecommons.org/licenses/by/4.0/). 